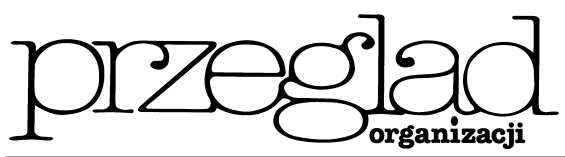

\title{
Wykorzystanie teorii gier do analizy układów koalicyjnych na walnych zgromadzeniach spółek z portfeli inwestycyjnych NFI
}

https://doi.org/10.33141/po.2005.78.02

\section{Andrzej Borczuch}

$\mathbf{R}$

ozwój teorii gier stał się stymulatorem, który w dużym stopniu przyczynił się do spopularyzowania strategii na gruncie nauk o zarządzaniu ${ }^{1}$. Teoria gier pozwala zidentyfikować warunki decyzji strategicznych w przedsiębiorstwie, dlatego można znaleźć wiele obszarów zastosowań tej dyscypliny wiedzy do modelowania strategii współczesnych podmiotów gospodarczych ${ }^{2)}$.

Współcześnie mówi się nawet o metaforze przedsiębiorstwa jako polityczno-społeczno-ekonomicznej grze. W metaforze tej zakłada się, że zróżnicowanie hierarchii i systemów wartości wyznawanych przez jej uczestników oraz istnienie różnych, na ogół rozbieżnych interesów i dążeń jest naturalną właściwością wszelkich złożonych systemów politycznych, społecznych, gospodarczych ${ }^{3}$. W związku z tym traktuje się występujące sprzeczności i konflikty jako obiektywny fakt społeczny o niekoniecznie destrukcyjnym charakterze, a nawet wręcz przeciwnie, jako istotny czynnik rozwoju i postępu. Natomiast reguły gry można interpretować jako zasady podziału ról organizacyjnych, określające dostęp do zasobów rzeczowych, informacji i władzy ${ }^{4}$. Należy podkreślić jeszcze, że „(...) metafora organizacji jako gry (...) nie znajduje się jeszcze w fazie normalnych badań, że wiedza naukowa rozwijana na jej podstawie dopiero narasta"5).

Centralnym obszarem badawczym organizacji jako systemów politycznych jest analiza konfliktów interesów pomiędzy ośrodkami sprawującymi władzę w podmiocie gospodarczym, zwłaszcza w przypadku, gdy żaden z tych ośrodków, podobnie jak w przypadku ciał ustawodawczych, nie ma wystarczającej siły, by samodzielnie sprawować władzę i jest zmuszony do tworzenia różnorodnych koalicji, by zrealizować swoje własne cele ${ }^{6)}$.

\section{Identyfikacja systemu władzy w Narodowych Funduszach Inwestycyjnych}

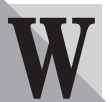
spółczesne organizacje gospodarcze w większości przypadków są spółkami kapitałowymi, których akcje bądź udziały znajdują się w posiadaniu wielu osób fizycznych lub prawnych. Na
Przegląd Organizacji, Nr 7/8 (786/787), 2005, ss. 11-15 www.przegladorganizacji.pl Towarzystwo Naukowe Organizacji i Kierownictwa (TNOiK) ogół żaden z akcjonariuszy lub udziałowców nie posiada wystarczającej liczby akcji, by samodzielnie sprawować kontrolę nad spółką kapitałową. Dużo częściej zdarza się sytuacja, w której na walnych zgromadzeniach spółek kapitałowych akcjonariusze łączą swoje akcje lub udziały w taki sposób, by posiadana liczba akcji była większa niż pakiet kontrolny, co zapewnia tym akcjonariuszom możliwość wpływu na zarządzanie spółką i realizację swoich własnych celów. W tym sensie akcjonariusze łączący swoje akcje lub udziały tworzą koalicję w znaczeniu politycznym. Przykłady takiej logiki procesu powstawania koalicji można znaleźć praktycznie w przypadku każdej spółki akcyjnej i spółki z ograniczoną odpowiedzialnością, w tym również w przypadku przedsiębiorstw uczestniczących w Programie Powszechnej Prywatyzacji, a więc wchodzących w skład portfeli inwestycyjnych Narodowych Funduszy Inwestycyjnych.

Realizacja Programu Powszechnej Prywatyzacji rozpoczęła się w 1993 r. uchwaleniem przez Sejm Rzeczypospolitej ustawy o narodowych funduszach inwestycyjnych i ich prywatyzacji ${ }^{7}$. W PPP uczestniczyło 512 przedsiębiorstw przekształconych w jednoosobowe spółki skarbu państwa, których akcje skarb państwa wniósł do portfeli inwestycyjnych NFI. Z założeń do Programu wynika, że akcje spółek uczestniczących w PPP zostały podzielone między poszczególne podmioty biorące udział w Programie w taki sposób, że żaden z nich samodzielnie nie mógł sprawować kontroli nad spółką nie mając pakietu kontrolnego. Dodatkowo w roku 1996 sześć NFI dokonało tzw. konsolidacji portfeli mniejszościowych polegającej na wymianie posiadanych 1,93\% pakietów w pięciu różnych przedsiębiorstwach na jeden $(9,65 \%) \mathrm{w}$ jednej spółce $^{8)}$. Przedstawione zależności są zaprezentowane w tabeli 1.

Z tabeli wynika, że w przypadku niedokonania przez część NFI konsolidacji pakietów mniejszościowych, fundusz, który był funduszem wiodącym dla danej spółki, posiadał 33\% akcji. Skarb państwa zatrzymał sobie $25 \%$ akcji spółki włączonej do Programu, pozostałe 14 funduszy posiadało $27 \%$ akcji (po $1,67 \%$ każdy), natomiast załogi przedsiębiorstw otrzymały $15 \%$ akcji. 
Tab. 1. Identyfikacja struktury głosów na walnym zgromadzeniu spółek z portfeli inwestycyjnych NFI

\begin{tabular}{|c|c|c|c|}
\hline \multicolumn{2}{|c|}{ Brak konsolidacji pakietów mniejszościowych } & \multicolumn{2}{|c|}{ Po konsolidacji pakietów mniejszościowych } \\
\hline Nazwa podmiotu & Liczba posiadanych akcji & Nazwa podmiotu & Liczba posiadanych akcji \\
\hline Fundusz wiodący & $33 \%$ & Fundusz wiodący & $33 \%$ \\
\hline Fundusze mniejszościowe & $27 \%$ (po $1,93 \%$ każdy) & Fundusze & \\
\hline Skarb państwa & $25 \%$ & mniejszosciowe (y) & $17,36 \%$ \\
\hline Pracownicy spółki & $15 \%$ & $\begin{array}{l}\text { Jeden z funduszy mniej- } \\
\text { szościowych }\end{array}$ & $9,64 \%$ \\
\hline & & Skarb państwa & $25 \%$ \\
\hline & & Pracownicy spółki & $15 \%$ \\
\hline
\end{tabular}

Źródło: opracowanie własne.

W przypadku, gdy akcje spółek stały się przedmiotem dokonanej konsolidacji przez część NFI, występuje pięć podmiotów posiadających akcje spółek: fundusz wiodący nadal posiadający $33 \%$ akcji, skarb państwa (25\% akcji), koalicja dziewięciu funduszy mniejszościowych (17,36\% akcji), pracownicy przedsiębiorstwa (15\% akcji) oraz jeden z funduszy mniejszościowych (fundusz posiadajacy 9,64\% akcji).

Jeżeli przyjmiemy, że pakiet większościowy stanowi 50\% + 1 akcja, to zarówno przed konsolidacją, jak i po dokonanej konsolidacji żaden z podmiotów posiadających akcje spółek z portfela inwestycyjnego NFI nie posiadał wystarczającej liczby głosów, aby samodzielnie sprawować władzę w tych spółkach. Zatem na walnym zgromadzeniu podmioty zmuszone zostały do tworzenia różnorodnych układów koalicyjnych, by osiągnąć wyznaczone cele. W świetle teorii gier najważniejszą kategorią jest więc pojęcie koalicji graczy. Koalicją graczy nazywamy każdy zbiór pojedynczych graczy świadomie koordynujących swoje działania ${ }^{9}$.

Jednym ze sposobów analizy układów koalicyjnych jest tzw. rozwiązanie elementarne, które obejmuje przede wszystkim analizę procesu przekształcenia koalicji przegrywającej, nie mającej większości na walnym zgromadzeniu, w koalicję wygrywającą, taką większość już posiadającą. Rozwiązanie takie zaproponował L. Shapley, koncentrując się na działaniach poszczególnych podmiotów - uczestników gry ${ }^{10}$. Shapley przedstawił formułę, dzięki której można wyznaczyć wartość każdego z uczestników gry jako układu politycznego. Wzór określający wartość L. Shapleya przedstawia się następująco:

$$
\Phi_{k}=\Sigma\left[v(K)-v(K /\{\mathrm{i}\}] \frac{(k-1) !(n-k) !}{n !}\right.
$$

gdzie:

$\Phi_{\mathrm{k}}$ - wartość Shapleya,

$\mathrm{v}(\mathrm{K})$ - wartość, jaka wnosi gracz k do koalicji, przekształcając ją w koalicję wygrywającą, k - liczba graczy tworzących koalicję wygrywająca, $\mathrm{n}$ - liczba graczy bioracych udział w grze ${ }^{11)}$.

Interpretacja wartości L. Shapleya jest następująca: podmiot przystępujący do koalicji, która przed jego wejściem do niej była koalicją wygrywającą lub do koalicji, która nadal jest przegrywającą, uzyskuje wartość równą zeru. Uczestnik koalicji posiada wartość większą od zera, jeżeli jego wejście do danej koalicji spowoduje, że przekształci się ona z koalicji przegrywającej w wygrywającą. Wartość L. Shapleya określa zatem częstotliwość, z jaką podmioty uczestniczące w grze kooperacyjnej potrafią współtworzyć koalicje wygrywające spośród wszystkich możliwych układów koalicyjnych w danej grze.

Na podstawie zaprezentowanych założeń scharakteryzowano dwa możliwe przypadki: brak konsolidacji pakietów mniejszościowych oraz po konsolidacji pakietów mniejszościowych.

\section{Analiza układów koalicyjnych w przypadku braku konsolidacji pakietów mniejszościowych NFI}

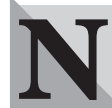

a podstawie danych o strukturze głosów na walnym zgromadzeniu spółek z portfela inwestycyjnego NFI oznaczmy grę następująco: $[0,33 ; 0,27 ; 0,25 ; 0,15 ; 0,51]$, a następnie zidentyfikujmy wszystkie możliwe koalicje graczy oraz uzyskane wypłaty, gdzie wartości liczbowe oznaczają strukturę głosów.

Podstawowym warunkiem utworzenia koalicji jest uzyskanie wymaganej większości głosów, a więc 51\% $(0,51)^{12)}$. Jeżeli dana koalicja jest koalicją wygrywająca, czyli taką, która posiada minimum 51\% głosów, to uzyskana przez nią wypłata będzie wynosić 1 . Natomiast wypłata pozostałych koalicji mniejszościowych wynosi 0 . Możliwe koalicje i wypłaty prezentuje tabela 2 .

Z tabeli wynika, że w przypadku czterech akcjonariuszy, którzy posiadają prawo głosu na walnym zgromadzeniu, liczba możliwych koalicji wynosi 15, przy

Tab. 2. Wypłaty w ważonej grze większości na walnym zgromadzeniu spółki

\begin{tabular}{|l|c|c|c|c|c|c|c|c|c|c|c|c|c|c|c|}
\hline Koalicja & 1 & 2 & 3 & 4 & 1,2 & 1,3 & 1,4 & 2,3 & 2,4 & 3,4 & $1,2,3$ & $1,2,4$ & $1,3,4$ & $2,3,4$ & $1,2,3,4$ \\
\hline Wypłata & 0 & 0 & 0 & 0 & 1 & 1 & 0 & 1 & 0 & 0 & 1 & 1 & 1 & 1 & 1 \\
\hline
\end{tabular}

Źródło: opracowanie własne. 
czym siedem z nich to koalicje mniejszościowe, natomiast osiem to koalicje wygrywające ${ }^{13)}$. Kolejnym krokiem procedury badawczej jest określenie możliwości każdego z podmiotów do tworzenia tzw. koalicji wygrywającej.

Każdy z graczy-akcjonariuszy dąży do zbudowania koalicji dysponującej na walnym zgromadzeniu większością głosów, jednak z punktu widzenia możliwości utworzenia koalicji wygrywającej, wartość posiadaja tylko ci akcjonariusze, których wejście do danej koalicji spowoduje, że dotychczasowa koalicja mniejszościowa przekształci się w koalicję wygrywająca (por. tabela 3). Kolumna „lista możliwych koalicji” obrazuje proces tworzenia koalicji, a więc wymienione są w niej wszystkie możliwe koalicje utworzone ze względu na kolejność przystąpienia każdego z graczy do danej koalicji.
Z zaprezentowanej tabeli wynika, że w przypadku funduszu wiodącego, pozostałych funduszy mniejszościowych oraz skarbu państwa jest osiem koalicji, w których głos każdego $\mathrm{z}$ tych trzech akcjonariuszy jest decydujący do utworzenia koalicji wygrywającej. Korzystając z formuły wyznaczającej wartość Shapleya możemy obliczyć średni wkład każdego z akcjonariuszy w koalicję wygrywającą. W tym przypadku jest on równy liczbie rozwiązań, przy których ten gracz jest decydujący, podzielonej przez liczbę wszystkich możliwych kombinacji, a więc 24 . W przypadku funduszy wiodących w danej spółce, funduszy mniejszościowych oraz skarbu państwa wartość Shapleya jest taka sama i wynosi $8 / 24=1 / 3$. Natomiast pracownicy spółki jako jej akcjonariusze z punktu widzenia utworzenia koalicji wygrywających mają wartość równą zeru.

Tab. 3. Lista możliwych koalicji wygrywających na walnym zgromadzeniu spółki z PPP

\begin{tabular}{|c|c|}
\hline Nazwa gracza & Lista możliwych koalicji wygrywających z udziałem danego akcjonariusza \\
\hline Fundusz wiodący & $(2,1 ; 4,3),(2,1 ; 3,4),(2,4,1 ; 3),(3,4,1 ; 2),(3,1 ; 2,4),(3,1 ; 4,2),(4,2,1 ; 4),(4,3,1 ; 2)$ \\
\hline Pozostałe fundusze & $(1,2 ; 3,4),(1,2 ; 4,3),(3,2 ; 1,4),(3,2 ; 4,1),(1,4,2 ; 3),(3,4,2 ; 1),(4,1,2 ; 3),(4,3,2 ; 1)$ \\
\hline Skarb państwa & $(1,3 ; 2,4),(1,3 ; 4,2),(1,4,3 ; 2),(2,3 ; 1,4),(2,3 ; 4,1),(2,4,3 ; 1),(4,1,3 ; 2),(4,2,3 ; 1)$ \\
\hline Pracownicy spółki & żadna \\
\hline
\end{tabular}

Źródło: opracowanie własne.

Tab. 4. Wypłaty w ważonej grze większości po konsolidacji

\begin{tabular}{|c|c|c|c|c|c|c|c|c|}
\hline Koalicja & 1 & 2 & 3 & 4 & 5 & 1,2 & 1,3 & 1,4 \\
\hline Wypłata & 0 & 0 & 0 & 0 & 0 & 1 & 1 & 0 \\
\hline Koalicja & 1,5 & 2,3 & 2,4 & 2,5 & 3,4 & 3,5 & 4,5 & $1,2,3$ \\
\hline Wypłata & 0 & 0 & 0 & 0 & 0 & 0 & 0 & 1 \\
\hline Koalicja & $1,2,4$ & $1,2,5$ & $1,3,4$ & $1,3,5$ & $1,4,5$ & $2,3,4$ & $2,3,5$ & $2,4,5$ \\
\hline Wypłata & 1 & 1 & 1 & 1 & 1 & 1 & 1 & 0 \\
\hline Koalicja & $3,4,5$ & $1,2,3,4$ & $1,2,4,5$ & $2,3,4,5$ & $1,2,3,4,5$ & \multirow{2}{*}{\multicolumn{3}{|c|}{ Źródło: opracowanie własne. }} \\
\hline Wypłata & 0 & 1 & 1 & 1 & 1 & & & \\
\hline
\end{tabular}

Tab. 5. Lista możliwych koalicji wygrywających po konsolidacji

\begin{tabular}{|c|c|}
\hline Nazwa gracza & Lista możliwych koalicji wygrywających $\mathbf{z}$ udziałem danego akcjonariusza \\
\hline Fundusz wiodący & $(2,1 ; 3,4,5),(2,1 ; 4,3,5),(2,1 ; 4,5,3),(2,1 ; 3,5,4),(2,1 ; 5,3,4),(2,1 ; 5,4,3),(2,3,1 ; 4,5),(2,3,1 ; 5,4)$, \\
& $(2,4,1 ; 3,5),(2,4,1 ; 5,3),(2,4,5,1 ; 3),(2,5,4,1 ; 3),(2,5,1 ; 3,4),(2,5,1 ; 4,3),(2,4,5,1 ; 3),(2,5,4,1 ; 3)$, \\
& $(3,1 ; 2,4,5),(3,1 ; 4,2,5),(3,1 ; 4,5,2),(3,1 ; 5,2,4),(3,1 ; 5,4,2),(3,1 ; 2,5,4),(3,2,1 ; 4,5),(3,2,1 ; 5,4)$, \\
& $(3,4,1 ; 2,5)(3,4,1 ; 5,2),(3,4,5,1 ; 2),(3,5,4,1 ; 2),(4,2,1 ; 3,5),(4,2,1 ; 5,3),(4,3,1 ; 2,5),(4,3,1 ; 5,2)$, \\
& $(4,5,1 ; 2,3),(4,5,1 ; 3,2),(4,2,5,1 ; 3),(4,5,2,1 ; 3),(4,3,5,1 ; 2),(4,5,3,1 ; 2),(5,2,1 ; 3,4),(5,2,1 ; 4,3)$, \\
& $(5,3,1 ; 2,4),(5,3,1 ; 4,2),(5,4,1 ; 2,3),(5,4,1 ; 3,2),(5,4,2,1 ; 3),(5,2,4,1 ; 3),(5,3,4,1 ; 2),(5,4,3,1 ; 2)$ \\
\hline Skarb państwa & $(1,2 ; 3,4,5),(1,2 ; 3,5,4),(1,2 ; 5,3,4),(1,2 ; 5,4,3),(1,2 ; 4,3,5),(1,2 ; 5,5,3),(1,4,2 ; 3,5),(1,4,2 ; 5,3)$, \\
& $(1,5,2 ; 3,4),(1,5,2 ; 4,3),(3,4,2 ; 1,5),(3,4,2 ; 5,1),(3,5,2 ; 1,4),(3,5,2 ; 4,1),(3,4,5,2 ; 1),(3,5,4,2 ; 1)$, \\
& $(4,1,2 ; 3,5),(4,1,2 ; 5,3),(4,3,2 ; 1,5),(4,3,2 ; 5,1),(4,3,5,2 ; 1),(4,5,3,2 ; 1),(5,1,2 ; 3,4),(5,1,2 ; 4,3)$, \\
& $(5,3,2 ; 1,4),(5,3,2 ; 4,1),(5,3,4,2 ; 1),(5,4,3,2 ; 1)$ \\
\hline Fundusze & $(1,3 ; 2,4,5),(1,3 ; 4,2,5),(1,3 ; 4,5,2),(1,3 ; 5,4,2),(1,3 ; 5,2,4),(1,3 ; 2,5,4),(1,4,3 ; 2,5),(1,4,3 ; 5,2)$, \\
mniejszościowe & $(1,5,3 ; 2,4),(1,5,3 ; 4,2),(2,4,3 ; 1,5),(2,4,3 ; 5,1),(2,5,3 ; 1,4),(2,5,3 ; 4,1),(2,4,5,3 ; 1),(2,5,4,3 ; 1)$, \\
& $(4,1,3 ; 2,5),(4,1,3 ; 5,2),(4,2,3 ; 1,5),(4,2,3 ; 5,1),(4,2,5,3 ; 1),(4,5,2,3 ; 1),(5,1,3 ; 2,4),(5,1,3 ; 4,2)$, \\
& $(5,2,3 ; 1,4),(5,2,3 ; 4,1),(5,2,4,3 ; 1),(5,4,2,3 ; 1)$ \\
\hline Pracownicy spółki & $(1,5,4 ; 2,3),(1,5,4 ; 3,2),(2,3,4 ; 1,5),(2,3,4 ; 5,1),(3,2,4 ; 1,5),(3,2,4 ; 5,1),(5,1,4 ; 2,3),(5,1,4 ; 3,2)$ \\
\hline Jeden z funduszy & $(1,4,5 ; 2,3),(1,4,5 ; 3,2),(2,3,5 ; 1,4),(2,3,5 ; 4,1),(3,2,5,1,4),(3,2,5 ; 4,1)(4,1,5 ; 2,3),(4,1,5 ; 3,2)$ \\
mniejszościowych & \\
\hline
\end{tabular}




\section{Analiza układów koalicyjnych w przypadku} konsolidacji pakietów mniejszościowych NFI

W przypadku funduszy biorących udział w konsolidacji pakietów mniejszościowych pojawiło się pięcioro graczy: fundusz wiodaccy, skarb państwa, koalicja dziewięciu funduszy mniejszościowych, pracownicy przedsiębiorstwa oraz jeden $\mathrm{z}$ funduszy mniejszościowych (fundusz posiadający $9,64 \%$ akcji). Zmieniła się także posiadana przez fundusze mniejszościowe liczba głosów (por. tabela 1). Zgodnie z podziałem głosów na walnym zgromadzeniu spółki zmodyfikowaną grę można oznaczyć następująco: $[0,33 ; 0,25 ; 0,17 ; 0,15 ; 0,09 ; 0,51]$. Natomiast listę możliwych koalicji oraz ich wypłaty w ważonej grze większości przedstawia tabela 4 .

$\mathrm{Z}$ tabeli wynika, że w przypadku spółki portfelowej po procesie konsolidacji pakietów mniejszościowych przez część NFI można utworzyć 29 koalicji, z których 14 to koalicje wygrywające, czyli posiadające większość na walnym zgromadzeniu spółki. Dlatego należy określić wartość każdego z graczy-akcjonariuszy z punktu widzenia utworzenia koalicji wygrywającej. W przypadku pięciu graczy liczba możliwych kombinacji wynosi $5 !=120$ (por. tabela 5 ). Z tabeli 5 wynika, że po konsolidacji pakietów mniejszościowych fundusz wiodący dla danej spółki decyduje o utworzeniu koalicji większościowej w 48 przypadkach, skarb państwa oraz 13 funduszy mniejszościowych traktowane jako koalicja decydują w 28 przypadkach, natomiast pracownicy spółki oraz jeden z funduszy mniejszościowych (posiadający 9,64\% akcji) decydują w ośmiu przypadkach o utworzeniu takiej koalicji.

Podobnie jak w poprzednim badaniu, należy wyznaczyć dla każdego akcjonariusza-gracza wartość Shapleya na walnym zgromadzeniu spółki uczestniczącej w PPP (por. tabela 6).

\section{Wnioski}

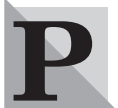

rzeprowadzona analiza układów koalicyjnych na walnych zgromadzeniach spółek z portfeli inwestycyjnych NFI pozwala na wysunięcie następujących wniosków.

- Z punktu widzenia gier kooperacyjnych, a zwłaszcza tzw. rozwiązania elementarnego, w przypadku, gdy

Tab. 6. Wartości Shapleya dla akcjonariuszy na walnym zgromadzeniu po konsolidacji

\begin{tabular}{|l|c|}
\hline \multicolumn{1}{|c|}{ Akcjonariusz } & Wartość Shapleya \\
\hline Fundusz wiodący & 0,4 \\
\hline Skarb państwa & 0,23 \\
\hline $\begin{array}{l}\text { Koalicja 13 funduszy mniejszo- } \\
\text { ściowych }\end{array}$ & 0,23 \\
\hline Pracownicy spółki & 0,07 \\
\hline $\begin{array}{l}\text { Jeden z funduszy mniejszościo- } \\
\text { wych (posiadający 9,64\% akcji } \\
\text { spółki) }\end{array}$ & 0,07 \\
\hline Razem & $\mathbf{1 , 0 0}$ \\
\hline
\end{tabular}

Źródło: opracowanie własne. żaden z akcjonariuszy nie posiada pakietu kontrolnego akcji bądź udziałów, najważniejsza nie jest posiadana liczba głosów, lecz zdolność do przekształcania dotychczasowej koalicji przegrywającej w tzw. koalicję wygrywającą. Dlatego przed procesem konsolidacji wartość Shapleya dla funduszy wiodących w danej spółce, funduszy mniejszościowych oraz skarbu państwa jest taka sama i wynosi $8 / 24=1 / 3$. Natomiast pracownicy spółki jako jej akcjonariusze, z punktu widzenia koalicji wygrywających mają wartość równą 0 , co oznacza, że na walnym zgromadzeniu, z punktu widzenia podejmowania decyzji strategicznych, znaczenie wiodącego NFI, skarbu państwa oraz funduszy mniejszościowych jest takie samo. Załoga przedsiębiorstwa miała minimalny wpływ na zarządzanie spółkami portfelowymi. Oznacza to, że fundusz wiodący bez zgody przynajmniej jednego $\mathrm{z}$ dwóch znacznych udziałowców nie może podjać żadnej istotnej decyzji dotyczącej zarządzania spółką.

- Koalicje budowane wokół strategii funduszu wiodącego w stosunku do spółek portfelowych z udziałem zbyt dużej liczby graczy nie są koalicjami stabilnymi w sensie warunków, jakie sformułowali: G. Romp, C.A. D'Aspremont i J.J. Gabszewicz ${ }^{14)}$.

- Po procesie konsolidacji przy podejmowaniu decyzji strategicznych dla danej spółki wzrasta znaczenie wiodącego NFI, pracowników przedsiębiorstwa oraz funduszu posiadającego 9,64\% akcji spółki. Spada natomiast znaczenie skarbu państwa oraz pozostałych funduszy mniejszościowych ${ }^{15)}$.

- Po konsolidacji pakietów mniejszościowych, jeżeli fundusz, który zwiększył udział w kapitale akcyjnym spółki, jest zgodny z funduszem wiodacym, wzrasta możliwość tworzenia koalicji stabilnych, gdyż koalicje wygrywające są wówczas mniej liczne niż przed konsolidacją pakietów mniejszościowych. Koalicje wygrywające mogą zostać wyłonione według wariantów obejmujących:

- fundusz wiodacy, skarb państwa (razem 58\% głosów), - fundusz wiodacy, fundusz posiadający $9,64 \%$ akcji, załogę przedsiębiorstwa (razem 57,64\% głosów). Wyłonione w ten sposób koalicje mają zbliżoną liczbę głosów na walnym zgromadzeniu akcjonariuszy spółki, posiadają tylko dwóch lub trzech członków, co zwiększa stabilność koalicji. Fundusz wiodący decydujący się budować koalicję z funduszem mniejszościowym posiadającym $9,64 \%$ akcji oraz z pracownikami spólki, jeżeli koalicja okaże się trwała, ogranicza w ten sposób wpływ na wybory strategiczne spółki przedstawicieli skarbu państwa, jak również funduszy mniejszościowych.

Przeprowadzona analiza obrazuje możliwość wykorzystywania modeli opracowanych na gruncie teorii gier do badania układów politycznych, takich jak $n p$. walne zgromadzenia akcjonariuszy i udziałowców spółek kapitałowych, a więc ciał, w których występuje przecież nierzadko sprzeczność interesów, a decyzje są na ogół podejmowane w wyniku wyłonienia koalicji mogących skutecznie taką decyzje przeforsować na walnym zgromadzeniu.

dr Andrzej Borczuch Katedra Zarządzania Przedsiębiorstwem Akademii Ekonomicznej w Katowicach 


\section{PRZYPISY}

1) Por. J. JEŻAK, Strategiczne zarzadzanie przedsiębiorstwem. Studium koncepcji i doświadczeń amerykańskich i zachodnioeuropejskich, Wyd. UŁ, Łódź 1990, s. 10.

2) A. BORCZUCH, Strategie dywersyfikacji Narodowych Funduszy Inwestycyjnych, nie publikowana rozprawa doktorska, AE, Katowice 2004, s. 55 i dalsze.

3) Por. G. MORGAN, Obrazy organizacji, PWN, Warszawa 2002, s. 162.

4) L.J. KRZYŻANOWSKI, O podstawach kierowania organizacjami inaczej: paradygmaty, modele, metafory, filozofia, metodologia, dylematy, trendy, PWN, Warszawa 1999 , s. $82-83$.

5) Tamże, s. 84.

6) Przykład zastosowania teorii gier do analizy układów koalicyjnych w ciałach ustawodawczych znajduje się w pracy: R.D. LUCE, H. RAIFFA, Gry i decyzje, PWN, Warszawa 1964 , s. $236-256$.

7) Ustawa o narodowych funduszach inwestycyjnych $i$ ich prywatyzacji z 30 kwietnia 1993 roku (Dz.U. nr 44, poz. 202).

8) A. KOSTRZ-KOSTECKA, Narodowe Fundusze Inwestycyjne na gietdzie, Wyd. Rzeczpospolita, Warszawa 1997, s. $115-116$.

9) Por. M. MALAWSKI, A. WIECZOREK, H. SOSNOWSKA, Konkurencja $i$ kooperacja. Teoria gier $w$ ekonomii $i$ naukach spotecznych, PWN, Warszawa 1997, s. 13.

10) Por. Z.J. PIETRAS, Teoria gier jako sposób analizy procesów podejmowania decyzji politycznych, UMCS, Lublin 1997, s. 106.

11) Por. A. SULEJEWICZ, Wspótpraca konkurencyjna przedsiębiorstw $w$ świetle teorii gier, Instytut Gospodarki Krajów Rozwijających Się, Kolegium Ekonomiczno-Społeczne, Szkoła Główna Handlowa, Warszawa 1994, s. 89.

12) W badaniu zostanie scharakteryzowany przypadek podejmowania decyzji zwykła większościa głosów. Przypadki podejmowania decyzji tzw. kwalifikowaną większością głosów zostana pominięte.

13) W przypadku pozostałych funduszy mniejszościowych mamy do czynienia nie z jednym akcjonariuszem, lecz z koalicją 14 graczy. Ponieważ fundusze mniejszościowe niekoniecznie muszą zgodnie głosować na walnym zgromadzeniu, zatem, korzystając z własności permutacji w odniesieniu do 14 funduszy mniejszościowych otrzymujemy 14!=87 178291200 dodatkowych koalicji. Ponieważ udział każdego z funduszy mniejszościowych w kapitale akcyjnym spółki jest taki sam, wartość każdego z nich z osobna z punktu widzenia tworzenia koalicji jest równa.

14) O stabilności koalicji decydują następujące czynniki:

1. Żaden z graczy-sygnatariuszy nie ma wystarczająco silnej motywacji do jednostronnego zerwania koalicji.

2. Żaden z graczy nie będących sygnatariuszami danej koalicji nie ma na celu wejścia do koalicji.

Jeżeli oba warunki zostaną spełnione równocześnie, liczba graczy tworzacych daną koalicję pozostanie stała, a koalicja jest koalicja stabilną. C.A. D'ASPERMONT, J.J. GABSZEWICZ, On the Stability of Collusion, [w:] G.F. MATTHEWSON, J.E. STIGLITZ, New Developments in the Analysis of Market Structure, Macmillan, New York 1986, cyt za: G. ROMP, Game Theory. Introduction and Applications, Oxford University Press, New York 1997, s. 222

15) Wzrost znaczenia wiodącego NFI dla danej spółki związany jest $\mathrm{z}$ faktem większego rozproszenia pozostałych akcji danej spółki i tym samym wzrostem znaczenia akcjonariusza mającego największy udział w kapitale akcyjnym spółki. 